\title{
nature
}

15 May 1997 Volume 387 Issue no 6630

\section{Setting priorities is painful but necessary}

The United States needs a credible and far-sighted body to provide the government with forthright advice on scientific priorities. Scientists should support the National Science Board in its efforts to fulfil this task.

s the US National Science Board playing with fire? Some of its own members fear that it may be doing so, as the board seeks to extend its remit from the narrow supervision of the National Science Foundation - the principal task for which it was created shortly after the Second World War - to the broader role of helping the federal government to coordinate all of its research activities (see page 220).

But someone has to do it. The 'endless frontier' of scientific discovery continues to expand in such marvellous and unexpected ways that no country, not even the United States, can push all of its boundaries at once. The one thing that is clear from the murky deal on a balanced budget that has just been reached by President Bill Clinton and the US Congress is that discretionary spending, of which science and technology are a large component part, will contract in real terms over the next five years, bringing difficult decisions in its wake.

The current arrangement that passes for US science policy, under which the president's political priorities collide somewhat haphazardly each summer with those of a dozen or so leaders in the Congress, does not serve the country well. Such a process is ill-equipped to make the tough choices that will undoubtedly have to be made as the United States' dominance of the world of science passes its peak, and other countries, both in Europe and among the emerging economies of Asia, come to rival its excellence in various fields.

The National Science Board is uniquely well-placed to offer advice on these choices: its founding charter of 1950, after all, asked it to offer science policy advice to the president and to the Congress. For a variety of reasons, the board has never really carried out this task.

Twenty years ago, the Congress was sufficiently frustrated by the resulting vacuum to pass laws establishing the Office of Science and Technology Policy (OSTP), to lead science policy from the White House. That has not always worked either: as a priority-setting body in successive administrations, OSTP tends to have been increasingly ignored in the White House and mistrusted in the Congress.

It should not be beyond the wit of a body such as the National Science Board to draw up a convincing science policy for the United States. Studies by the Committee of Science, Engineering and Public Policy at the National Academy of Sciences have already shown how priorities could be identified. A panel of the academy, chaired by its former president (and presidential science adviser), Frank Press, laid out guidelines two years ago on how they could be implemented.

The fragmentation of control over science policy in the Congress remains a major obstacle to any such implementation. But there are strong indications that specific policy recommendations from a credible source would be well-received on Capitol Hill.

It is hardly appropriate for scientists to complain incessantly about the arbitrariness of the congressional budget process while steadfastly refusing to offer much-needed advice on what should be funded and what should not. The National Science Board is at least attempting to break this unseemly silence. It will be a sad reflection on the true priorities of US scientists if the attempt is snuffed out by those who fear the outcome of an honest attempt at selecting research priorities.

\section{Now for the hard part}

\section{Britain's Labour party still needs to show how it intends to put science 'at the heart of government'.}

- orget 100 days. Britain's new Labour government has already hit the ground running, as it had pledged. There have been some unexpected - and significant — announcements, such as the decision to give the Bank of England full independence to set interest rates. And there have also been welcome moves already promised, such as the creation of a separate food standards agency.

But where is science in all this? Those who had been pressing Labour to appoint a cabinet minister solely responsible for science were disappointed, although perhaps not surprised, as the party had previously declined to make this commitment. Equally unsurprising is that there has not been any move to remove responsibility for the science base from the Department of Trade and Industry.

Even if some disagree with these decisions, there are sound reasons for both, related to the need to establish strong links between science and the country's industrial base. But there remains a genuine concern over what little has yet emerged about how science will be handled at the top levels of government. In particular, while responsibility for science has been given to a full minister, the portfolio has been merged not only with manufacturing but also with energy - an area which, only a few years ago, merited a whole ministry on its own.
No-one disputes either the energy or the commitment of John Battle, the opposition spokesman on science between 1994 and 1995, who has been selected to fill this post. But with many pressing demands on his agenda, such as energy regulation, will he really have the time to devote to science that it both deserves and requires?

The Labour party now has a considerable pool of talent in its ranks. Some have a proven track record, such as Anne Campbell, chair of the Parliamentary and Scientific Committee, and other members of the former House of Commons Select Committee on Science and Technology. New recruits also bring valuable skills. These include Ian Gibson, dean of biological science at the University of East Anglia and now Member of Parliament for Norwich (North), and Phyllis Starkey, formerly a policy and assessment expert with the Biotechnology and Biological Sciences Research Council, who now represents Milton Keynes.

In addition, several prominent scientists would no doubt welcome an opportunity to become closely involved with the development of an effective long-term and cross-government strategy (see above). Few will forget Tony Blair's commitments to place science "at the heart of government". 